\title{
ВЫСОКОДИФФЕРЕНЦИРОВАННЫЕ МИКРОКАРЦИНОМЫ ЩИТОВИДНОЙ ЖЕЛЕЗЫ
}

\author{
И.В. Дейнеко, С.П. Меренкова, Э.В. Жмуренко \\ КУ «Областная клиническая больница им. И.И. Мечникова», г. Днепр
}

Введение. По данным различных исследований, показатель заболеваемости раком щитовидной железы (РЩЖ) в разных странах варьирует от 0,8 до 9,4 новых случаев на 100000 населения в год среди женщин и от 0,6 до 2,6 - среди мужчин [1]. B частности, по данным L. Leenhardt и соавт. в Европе доля микрокарцином увеличилась с 18,4 до $43,1 \%$ за последние два десятилетия. Кроме того, в 15-35,6\% случаев данных опухолей отмечается мультифокальный тип поражения [3]. Наряду с термином «микрокарцинома», в зависимости от метода диагностики и клинического течения, В отношении данных новообразований широко применяются термины «скрытая», «субклиническая» или Т1а опухоль (менее 1,0 cм) по классификации TNM [2]. Учитывая возможность определения генотипа опухоли, В литературе приведены рекомендации по выполнению органосохраняющих операций и даже наблюдению опухолей, например, инкапсулированного фолликулярного варианта папиллярного рака. Также необходимо отметить радиационное облучение в анамнезе украинцев, В связи с Чернобыльской катастрофой, что номинально переводит пациентов В группу среднего риска.

Цель: оценить особенности клинического течения микрокарцином щитовидной железы и результаты их хирургического лечения.

Результаты. С 2004 по 2018 г.г. в отделении эндокринной хирургии было прооперировано 1611 больных с РЩЖ, из них микрокарциномы составили 245 (15,2\%) случаев. По данным патогистологического исследования в большинстве случаев выявлена папиллярная форма рака - у 228 (93,0\%) пациентов, фолликулярная форма - у 17 (7,0\%). По степени распространенности процесса: солитарная опухоль диагностирована у 220 (89,7\%) пациентов, мультифокальное поражение - у 25 (10,3\%). При микрокарциноме метастазы в регионарные лимфоузлы по данным УзИ до операции диагностированы в 24 (9,8\%) случаев.

Большинству больных была выполнена экстафасциальная тиреоидэктомия с передней либо модифицированной лимфодиссекцией шеи. Согласно интраоперационным и гистологическим данным метастатические поражения регионарных лимфоузлов были выявлены в 61 случае (25\%). В том числе у $28(11,4 \%)$ пациентов имело место поражение лимфоузлов III, V, VII коллектора, то есть N1b. Органосохраняющие операции проводились в последние 2 года у 24 (9,8\%) больных, при условии солитарной опухоли T1aNO. Передняя диссекция шеи сгистологическим исследованием проводилась всем пациентам.

В ходе исследования у пациентов с микрообразованиями щитовидной железы не выявлено каких-либо клинических особенностей и жалоб.

Всем больным в послеоперационном периоде проводилось диагностическое сканирование с определением тиреоглобулина, а в случае наличия метастазов - лечебный курс радиойода и супрессивная терапия.

В трехлетнем периоде медиана выживаемости составила 99\%, однако у $15(6,1 \%)$ пациентов имело место рецидивирование заболевания в лимфатические узлы шеи, причем у 5 больных на момент операции гистологически подтвержденных метастазов не определялось. Также нами выявлено 8 (3,2\%) случаев запущенного регионарного метастазированияприединичноймикрокарциноме.

Выводы. Таким образом, мы считаем, что при отсутствии условий проведения полноценного генотипирования опухоли, выполнение органосохраняющих операций возможно в случае пациента младше 1987 года рождения, женского пола, при отсутствии метастазов в лимфоузлах шеи. Остальным больным целесообразно проведение радикальных операций. Зачастую клиническое течение при микрокарциномах бессимптомно, поэтому периодическая скрининговая диагностика заболеваний щитовидной железы целесообразна и необходима для раннего выявления злокачественных опухолей.

\section{ЛИТЕРАТУРА}

1. Ивахно И.В. Основные морфологические 
признаки метастазирующих папиллярных микрокарцином щитовидной железы / И.В. Ивахно // Вісник проблем біології і медицини. 2014. - Т. 3, №. 4. - С. 266-269.

2. Папиллярная микрокарцинома щитовидной железы / В.А. Смирнова, Г.В. Семкина, Н.М. Платонова, В.Э. Ванушко // Клиническая и экспериментальная тиреоидология. - 2015. - Т. 11, №. 2. - С. 11-24.

Дата надходження до редакиії 18.10.2018 p.
3. Leenhardt $L$. Increased incidence of thyroid carcinoma in France: a true epidemic or thyroid nodule management effects? Report from the French Thyroid Cancer Committee / L. Leenhardt, P. Grosclaude, L. Chérié-Challine // Thyroid. - 2004. Vol. 14, N. 12. - P. 1056-1060.

https://doi.org/10.24026/1818-1384.4(64).2018.150163

\title{
КЛІНІКО-ПАРАКЛІНІЧНІ ХАРАКТЕРИСТИКИ АНДРОГЕНОВОГО ДЕФІЦИТУ У ЖІНОК РЕПРОДУКТИВНОГО ВІКУ
}

\author{
Л.В. Дем'яненко \\ Український науково-практичний иентр ендокринної хірургії, \\ трансплантації ендокринних органів і тканин МОЗ України.
}

Не дивлячись на те, що дотепер не існує «золотого стандарту» для виявлення андрогенового дефіциту в клінічній практиці, дослідження в цьому напрямку проводяться. Європейська ендокринологічна спільнота вважає, що ці заходи необхідні для виявлення прийнятного з клінічної точки зору визначення, що відповідає синдрому дефіциту андрогенів у жінок, які були 6 основані на вимірюваних параметрах андрогенів і конкретних клінічних проявах жіночої андрогенової недостатності.

Мета: виявити клінічні характеристики недостатності андрогенів у жінок репродуктивного віку.

Матеріали і методи. Нами обстежено 80 жінок репродуктивного віку, що мали основні скарги на сексуальні порушення (зниження лібідо та відсутність оргазму, а також диспареунію) і 30 здорових жінок репродуктивного віку без скарг на розлади в сексуальному здоров'ї. Використовували метод анкетування пацієнтів з детальним вивченням соціально-економічного статусу, соматичного, гінекологічного, акушерського та сексуального анамнезу, загальноклінічний та гінекологічний огляд.

Результати і обговорення. Важливість андрогенів для організму людини пояснюється знаходженням андрогенових рецепторів у клітинах більшості тканин: молочної залози, серця, кровоносних судин, шлунково-кишкового тракту (ШКТ), легень, ЦНС і периферичних нервах, шкірі, кістково-м'язовому апараті, кістковому мозку, матці, яєчниках, зовнішніх статевих органах, жировій тканині. Проаналізувавши дані анкетування та загальноклінічного і гінекологічного оглядів, та виключивши пацієнток 3 соматичною та гінекологічною патологією, ми виявили, що дефіцит андрогенів у жінок проявлявся сексуальними порушеннями у 100\% (80 пацієнток) основної групи (зниженням лібідо, порушенням сексуального задоволення та відсутністю оргазму). Також виявили інші патологічні симптоми, включаючи зміни настрою (дратівливість, тривожність, депресія) у 80\% (64 пацієнтки) основної групи, в той час як в контрольній групі лише у $20 \%$ (6 жінок). Скарги на погане самопочуття, швидку втомлюваність, слабкість були характерними для $67 \%$ (54) жінок основної групи і 20\% (6) - контрольної. Порушення пам'яті та когнітивних функцій відзначали 56\% (45) пацієнток основної групи і 17\% (5) контрольної. Порушення сечовипускання, в тому числі нетримання сечі, не пов'язані з органічною патологією сечовивідних шляхів, діагностовано у 49\% (39) жінок основної і 4\% (1) контрольної групи. Відомі ефекти андрогенів на стан м'язів тазового дна та слизових оболонок зовнішніх статевих органів у жінок. У нашому дослідженні було виявлено атрофічні зміни слизової оболонки піхви та екзоцервіксу у 70\% (56) жінок основної групи і 